\title{
ANALISA FAKTOR-FAKTOR YANG MEMPENGARUHI KINERJA KARYAWAN
}

\author{
SURYA AKBAR \\ Program Studi Ilmu Administrasi Negara STIA Indragiri \\ Jl. Azki Aris, Rengat. Kode Pos 29318. Telp. (0769) 22458
}

\begin{abstract}
Abstrak :
Sumber daya manusia (SDM) atau tenaga kerja merupakan aset utama dalam sebuah organisasi, perlu perlakuan khusus dalam pengelolaan tenaga kerja karena dasarnya adalah tenaga kerja dapat mempengaruhi eksistensi organisasi dimasa yang akan datang. Pengelolaan tenaga kerja yang baik akan mampu menciptakan suasana kerja yang optimal dalam rangka mewujudkan produktifitas tenaga kerja dalam organisasi. Ada banyak sekali faktor yang dapat mempengaruhi kinerja karyawan dalam bekerja diantaranya adalah proses recruitment dan pemberian motivasi kepada karyawan. Proses rekrutmen karyawan membutuhkan perencanaan yang baik terkait kebutuhan organisasi akan tenaga kerja serta perlu analisa yang baik pula dalam menempatkan seorang pekerja pada posisi yang sesuai dengan kompetensinya. Selanjutnya, pemberian motivasi merupakan faktor penting lainnya dalam meningkatkan hasil kerja karyawan. Pemberian motivasi oleh sebuah organisasi merupakan suatu kewajiban dan tuntutan, dengan pemberian motivasi yang baik dan berkelanjutan dalam bentuk arahan atau penghargaan kepada karyawan dapat memberikan rangsangan kepada karyawan untuk bekerja lebih baik lagi dalam rangka mencapai tujuan organisasi yang telah ditetapkan semula.
\end{abstract}

Kata Kunci : Sumber Daya Manusia, recruitment, motivasi dan eksistensi

\section{Abstract :}

Human resources $(H R)$ or labor are the main assets in an organization, need special treatment in the management of labor because the basis is labor can affect the existence of the organization in the future. The management of a good workforce will be able to create an optimal working atmosphere in order to realize the productivity of the workforce in the organization. There are many factors that can affect employee performance in work, including the process of recruitment and giving motivation to employees. The process of employee recruitment requires good planning related to the organization's needs for labor and needs a good analysis in placing a worker in a position that is in accordance with his competence. Furthermore, giving motivation is another important factor in improving employee work outcomes. Giving motivation by an organization is an obligation and demand, with good and continuous motivation in the form of direction or appreciation to employees can provide stimulation to employees to work better in order to achieve organizational goals that have been set.

Keywoord : Human Resources, recruitment, motivation and existence 


\section{Pendahuluan}

Kita dapat mengawali pembahasan ini dengan sebelumnya mengerti terlebih dahulu apa itu kinerja. Kinerja karyawan (prestasi kerja) adalah hasil kerja secara kualitas dan kuantitas yang dicapai oleh seseorang pegawai dalam melaksanakan tugasnya sesuai dengan tanggung jawab yang diberikan kepadanya (Mangkunegara, 2009: 18). Sedangkan menurut Sedarmayanti (2011: 260), kinerja adalah terjemahan dari performance yang berarti hasil kerja seorang pekerja, sebuah proses manajemen atau suatu organisasi secara keseluruhan, dimana hasil kerja tersebut harus dapat ditunjukkan buktinya secara konkrit dan dapat diukur (dibandingkan dengan standar yang telah ditentukan).

Berdasarkan pengertian dari para ahli diatas mengenai istilah dan definisi dari sebuah kinerja maka dapat kita simpulkan bahwa kinerja merupakan suatu usaha yang maksimal yang dikeluarkan oleh para pekerja dalam rangka menggapai suatu prestasi kerja yang memuaskan, artinya apabila suatu pekerjaan tersebut dapat diselesaikan dengan hasil yang memuaskan akan memberikan dampak positif terhadap pribadi pekerja dan lingkungan tempatnya bekerja.

Studi terhadap kinerja ini sangatlah penting, untuk dapat memberikan pemahaman kepada semua elemen di dunia kerja mengenai pentingnya produktifitas kerja dalam bekerja. Dapat kita bayangkan bersama seandainya dalam dunia kerja para pekerjanya memiliki pola kerja yang biasabiasa saja atau mungkin pola kerja yang cenderung malas dan tidak disiplin apa yang akan terjadi terhadap lingkungan pekerjaan tersebut tentunya sesuatu hal yang dapat merugikan semua pihak di lingkungan kerja itu.

Apabila kita berbicara tentang sebuah kinerja maka akan sangat erat kaitannya dengan produktifitas kerja yang ditunjukkan SDM (Suber Daya Manusia) yang ada di dalamnya. Penelitian ini akan membahas secara mendasar tentang pentingnya kinerja dalam kajian Manajemen Sumber Daya Manusia. Selain itu, melalui penelitian ini juga akan memberikan manfaat kepada kita tentang apa-apa saja faktor yang dapat mempengaruhi kinerja SDM dalam suatu lingkungan kerja.

\section{Pembahasan}

Seperti yang telah diuraikan sebelumnya dari pendahuluan di atas tentang arti pentingnya kinerja yang memiliki kaitan erat dengan keilmuan Manajemen Sumber Daya Manusia (MSDM) maka kita juga dituntut untuk mampu memahami kedua istilah tersebut yakni kinerja dan kaitannya dengan MSDM. Sumber Daya Manusia ( Human Resource ) merupakan kemampuan terpadu dari daya pikir dan daya fisik individu yang dirancang dengan sistem-sistem formal dalam sebuah organisasi untuk memastikan penggunaan bakat manusia secara efektif dan efisien guna mencapai tujuan organisasi (Hasibuan, 2005: 23). Berdasarkan pengertian tentang SDM menurut Malayu Hasibuan ini, maka dapat diuraikan bahwa SDM terbagi menjadi :

1. Manusia sebagai sumber daya fisik Dengan energi yang tersimpan dalam ototnya, manusia dapat bekerja dalam berbagai bidang, antara lain: bidang perindustrian, transportasi, perkebunan, perikanan, perhutanan, dan peternakan.

2. Manusia sebagai sumber daya pikir/ mental.

Kemampuan berpikir manusia merupakan suatu sumber daya yang sangat penting, karena berfikir merupakan landasan utama bagi kebudayaan. Oleh karena itu, manusia tidak dilihat hanya sebagai 
sumber energi, tapi yang terutama ialah sebagai sumber daya cipta (sumber daya mental) yang sangat penting bagi perkembangan kebudayaan manusia.

Dalam hal ini dapat kita pahami bahwa manusia merupakan salah satu aset penting dalam dunia kerja selain dari aset tidak hidup lainnya, dalam dunia kerja tentunya ada perbedaan yang sangat mendasar antara perlakuan terahadap aset hidup yakni manusia dengan aset tidak hidup seperti teknologi, barang dan fasilitas pendukung pekerjaan lainnya. Manusia selain memiliki fisik juga memiliki pikiran/ mental serta perasaan. Perlu adanya perlakuan khusus untuk dapat mengelola akal, pikiran dan mental SDM dalam sebuah pekerjaan.

MSDM merupakan salah satu kajian yang dianggap penting karena pembahasan secara mendasar dalam kajian MSDM adalah menitikberatkan permasalahan terhadap SDM nya. Manajeman sumber daya manusia dianggap sebagai suatu ilmu yang mempelajari tentang cara-cara memaksimalkan sumber daya yang ada pada individu secara efisien dan efektif untuk mencapai tujuan yang diinginkan.

\section{II.a. Pentingnya Manajemen Sumber Daya Manusia}

Manajemen sumber daya manusia adalah ilmu dan seni yang mengatur hubungan dan peranan tenaga kerja agar efektif dan efisien membantu terwujudnya tujuan perusahaan, karyawan dan masyarakat (Hasibuan, 2005 : 98).

Perubahan teknologi dan kemajuan zaman menggeser fungsi-fungsi MSDM yang selama ini dianggap hanya meliputi kegiatan administrasi saja, mengalami perubahan dari fungsi spesialisasi tersebut menjadi fungsi yang lebih terintegrasi dengan seluruh fungsi di dalam suatu organisasi, untuk bersama-sama mencapai sasaran yang sudah ditetapkan serta memiliki fungsi perencanaan yang sangat strategik.

Karyawan atau Sumber Daya Manusia (SDM) merupakan satu-satunya aset perusahaan yang bernapas dan hidup disamping aset-aset lainnya yang tidak hidup seperti :

- Modal

- Bangunan gedung

- Mesin

- Peralatan Kantor

- Persediaan Barang, dsb

Dalam hal ini tentunya perlu perlakuan yang berbeda antara aset hidup (SDM) dengan aset yang tak hidup tersebut, menimbang bahwa SDM dan tenaga kerja merupakan faktor utama keberhasilan suatu organisasi atau perusahaan tertentu. Untuk itu, perlu adanya manajemen dan pengelolaan yang baik terhadap SDM tersebut.

Manajemen SDM awalnya hanya identik dengan kegiatan administrasi bagian karyawan dan manajemen yang sifatnya fungsional seperti : Perekrutan, pelatihan, pengupahan, pemasaran, keuangan, produksi dan lainnya.

Selanjutnya, Sistem Manajemen SDM berevolusi dan beradaptasi dengan lingkungan yang dipengaruhi oleh perubahan zaman dan kemajuan teknologi artinya suatu organisasi melalui MSDM nya harus mampu mengantisipasi berbagai perkembangan yang sedang dan akan terjadi.

Perubahan yang dimaksud:

- Merubah perannya yang hanya berorientasi pada "result".

- Merubah sistem kerja responsive menjadi proaktif.

- Merubah struktur yang fungsional menjadi fleksibel.

Hingga pada akhirnya kajian didalam MSDM tidak lagi hanya 
berorientasi kepada hasil saja namun penting untuk memahami proses yang ada. Tujuan suatu organisasi atau perusahaan tidak akan tercapai apabila hanya menitikberatkan kepada hasil dan mengenyampingkan faktor proses dalam meraih tujuan tersebut. Pengelolaan terhadap SDM merupakan salah satu proses yang perlu dibahas dalam MSDM.

Menurut Malayu S.P Hasibuan (2005: 21), menjelaskan secara singkat fungsi-fungsi Manajemen SDM sebagai berikut :

\section{Fungsi Manajerial : a. Perencanaan (Planning).}

Merencanakan tenaga kerja secara efektif dan efisien agar sesuai dengan kebutuhan perusahaan dalam mewujudkan tujuan.

\section{b. Pengorganisasian (Organizing).}

Menyusun suatu organisasi dengan mendesain struktur dan hubungan antara tugas-tugas yang harus dikerjakan oleh tenaga kerja yang dipersiapkan.

\section{c. Pengarahan (Directing).}

Kegiatan mengarahkan semua karyawan agar mau bekerjasama dan bekerja secara efektif dan efisien dalam membantu tercapainya tujuan perusahaan, karyawan, dan masyarakat.

\section{d. Pengendalian (Controlling).}

Kegiatan mengendalikan semua karyawan agar mentaati peraturan-peraturan perusahaan dan bekerja sesuai dengan rencana.

\section{Fungsi Operasional :}

1. Pengadaan tenaga kerja :

- Perencanaan SDM

- Analisis Jabatan

- Penarikan Pegawai (Recruitment)

- Penempatan kerja

- Orientasi Kerja (Job Decription)

\section{Pengembangan tenaga kerja :}

- Pendidikan dan pelatihan (training and development)

- Pengembangan (Karier)

- Penilaian Prestasi kerja

\section{Pemberian Balas Jasa mencakup :}

- Balas jasa langsung seperti gaji/ upah dan insentif.

- Balas jasa tak langsung seperti keuntungan (benefit) dan pelayanan/ kesejahteraan.

\section{Integrasi :}

- Kebutuhan karyawan

- Motivasi kerja

- Kepuasan kerja

- Partisipasi kerja

\section{Pemeliharaan tenaga kerja :}

- Komunikasi kerja

- Kesehatan dan keselamatan kerja

- Pengendalian konflik kerja

- Konseling kerja

\section{Pemisahan tenaga kerja :}

- Pemberhentian karyawan.

\section{II.b. Faktor yang mempengaruhi pencapaian kinerja}

Tinggi rendahnya kinerja seorang pegawai tentunya ditentukan oleh faktorfaktor yang mempengaruhinya baik secara langsung ataupun tidak langsung.

Anwar Prabu Mangkunegara (2009:67) menyatakan bahwa:

"Faktor yang mempengaruhi pencapaian kinerja adalah faktor kemampuan (ability) dan faktor motivasi (motivation).

Sedangkan menurut Keith Davis dalam Anwar prabu Mangkunegara (2009:67) dirumuskan bahwa faktor-faktor yang dapat mempengaruhi kinerja adalah : 


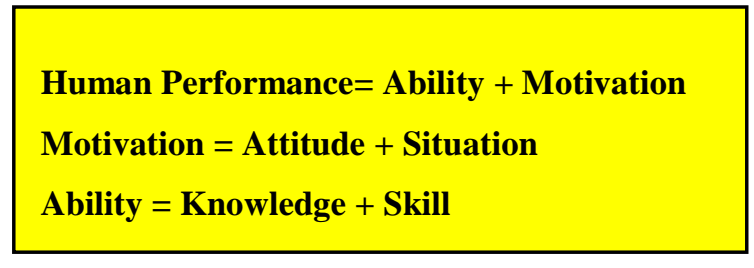

Penjelasan :

\section{Faktor Kemampuan}

Secara psikologis, kemampuan (Ability) pegawai terdiri dari kemampuan potensi (IQ) dan kemampuan reality (knowledge + Skill). Artinya, pegawai yang memiliki IQ rata-rata (IQ $110-120$ ) dengan pendidikan yang memadai untuk jabatannya dan terampil dalam mengerjakan pekerjaannya sehari-hari, maka ia akan lebih mudah mencapai prestasi kerja yang diharapkan. Oleh karena itu, pegawai perlu ditempatkan pada pekerjaan yang sesuai dengan keahliannya (the right man on the right place, the right man on the right job).

\section{Faktor Motivasi}

Motivasi terbentuk dari sikap seorang pegawai dalam menghadapi situasi kerja. Motivasi merupakan kondisi yang menggerakkan diri pegawai yang terarah untuk mencapai tujuan organisasi (tujuan kerja).

Sikap mental merupakan kondisi mental yang mendorong diri pegawai untuk berusaha mencapai prestasi kerja secara maksimal. Sikap mental seorang pegawai harus sikap mental yang siap secara psikofisik (sikap secara mental, fisik, tujuan dan situasi). Artinya seorang pegawai harus siap mental, mampu secara fisik, memahami tujuan utama dan target kerja yang akan dicapai serta mampu memanfaatkan dan menciptakan situasi kerja.

Selain itu, menurut A. Dale Timple yang dikutip oleh Anwar Prabu
Mangkunegara (2006:15) faktor-faktor kinerja terdiri dari faktor internal dan faktor eksternal :

"Faktor internal yaitu faktor yang dihubungkan dengan sifat-sifat seseorang. Sedangkan faktor eksternal adalah faktor-faktor yang mempengaruhi kinerja seseorang yang berasal dari lingkungan. Seperti perilaku, sikap, dan tindakan-tindakan rekan kerja, bawahan atau pimpinan, fasilitas kerja, dan iklim organisasi."

Dari uraian di atas dapat disimpulkan bahwa faktor yang mempengaruhi kinerja dapat bersumber dari dalam individu pegawai maupun dari luar individu. Tinggal bagaimana kebijakan organisasi mampu menyelaraskan antara faktor-faktor tersebut.

Selain itu, dari referensi lainnya menurut Robert L. Mathis dan John $\mathrm{H}$. Jackson (2001: 82) faktor-faktor yang memengaruhi kinerja individu tenaga kerja, yaitu :

1. Kemampuan

2. Motivasi

3. Dukungan yang diterima

4. Keberadaan pekerjaan yang mereka lakukan

5. Hubungan mereka dengan organisasi

Lebih lanjut Gibson menjelaskan ada 3 faktor yang berpengaruh terhadap kinerja :

1) Faktor individu: kemampuan, ketrampilan, latar belakang keluarga, pengalaman kerja, tingkat sosial dan demografi seseorang.

2) Faktor psikologis : persepsi, peran,sikap, kepribadian, motivasi dan kepuasan kerja 
3) Faktor organisasi.

Menurut Bernardin berhasil tidaknya kinerja yang telah dicapai oleh suatu organisasi, dipengaruhi oleh tingkat kinerja dari karyawan, baik secara individual maupun secara kelompok, dengan asumsi bahwa semakin baik kinerja karyawan maka diharapkan kinerja organisasi akan semakin baik. Sehubungan dengan hal itu, pendekatan untuk mengukur sejauh mana kinerja karyawan secara individual ada enam kriteria, yaitu : (Robbins, 2002:260)

1. Kualitas kerja

Kualitas kerja dapat diukur dari persepsi karyawan terhadap kualitas pekerjaan yang dihasilkan serta kesempurnaan tugas terhadap keterampilan dan kemampuan karyawan.

2. Kuantitas

Kuantitas kerja dapat diukur dari persepsi karyawan terhadap jumlah aktivitas yang ditugaskan beserta hasilnya.

3. Ketepatan waktu

Ketepatan waktu diukur dari persepsi karyawan terhadap suatu aktivitas yang diselesaikan di awal waktu sampai menjadi output.

4. Efektivitas Tingkat penggunaan sumber daya organisasi (tenaga, uang, teknologi, bahan baku) dimaksimalkan dengan maksud menaikkan hasil dari setiap unit di dalam penggunaan sumber daya, efektivitas kerja karyawan dalam menilai pemanfaatan waktu dalam menjalankan tugas, efektivitas penyelesaian tugas yang dibebankan organisasi.

5. Kemandirian

Merupakan tingkat kemampuan seseorang dalam melakukan fungsi kerjanya tanpa meminta bantuan, bimbingan dari orang lain atau pengawas.
6. Komitmen kerja

Merupakan tingkat dimana karyawan mempunyai komitmen kerja dengan instansi dan tanggung jawab terhadap organisasi.

Faktor-faktor yang mempengaruhi kinerja menurut Siagian (2002) menyatakan bahwa kinerja karyawan dipengaruhi beberapa faktor, yaitu : kompensasi, lingkungan kerja, budaya organisasi, kepemimpinan, dan motivasi kerja , disiplin kerja, kepuasan kerja, komunikasi dan faktor faktor lainnya.

Selain itu, faktor-faktor yang mempengaruhi kinerja menurut Handoko (2001:193) yaitu :

a) Motivasi

Merupakan faktor pendorong penting yang menyebabkan manusia bekerja adalah adanya kebutuhan yang harus dipenuhi. Kebutuhankebutuhan ini berhubungan dengan sifat hakiki manusia untuk mendapatkan hasil terbaik dalam kerjanya.

b) Kepuasan kerja

Kepuasan kerja mencerminkan perasaan seseorang terhadap pekerjaannya. Hal ini terlihat dari sikap positif karyawan terhadap pekerjaan dan segala sesuatu yang dihadapi di lingkungan kerjanya.

c) Tingkat stres

Stres merupakan suatu kondisi ketegangan yang mempengaruhi emosi, proses berpikir dan kondisi sekarang. Tingkat stres yang terlalu besar dapat mengancam kemampuan seseorang untuk menghadapi lingkungan sehingga dapat mengganggu pelaksanaan pekerjaan mereka.

d) Kondisi pekerjaan

Kondisi pekerjaan yang dimaksud dapat mempengaruhi kinerja disini adalah tempat kerja, ventilasi, serta penyinaran dalam ruang kerja. 
e) Sistem kompensasi

Kompensasi merupakan tingkat balas jaa yang diterima oleh karyawan atas apa yang telah dilakukannya untuk perusahaan. Jadi, pemberian kompensasi harus benar agar karyawan lebih semangat untuk bekerja.

f) Desain pekerjaan Desain pekerjaan merupakan fungsi penetapan kegiatan-kegiatan kerja seorang individu atau kelompok karyawan secara organisasional. Desain pekerjaan harus jelas supaya karyawan dapat bekerja dengan baik sesuai dengan pekerjaan yang telah diberikan kepadanya.

Kemungkinan besar kinerja karyawan berkurang apabila salah satu faktor ini berkurang atau tidak ada. Sebagai contoh beberapa karyawan memiliki kemampuan untuk melakukan pekerjaannya dan bekerja keras, tetapi organisasi memberikan peralatan yang kuno. Masalah kinerja merupakan hasil kerja yang dicapai seseorang dalam melaksanakan tugas dan tanggung jawab yang dibebankan kepada karyawan. Kinerja meliputi kualitas output serta kesadaran dalam bekerja.

Ada banyak faktor yang dapat memberikan pengaruh kepada kualitas kerja karyawan dalam sebuah organisasi dari beberapa penjelasan oleh para ahli, maka dapat diperjelas melalui gambar berikut :
Gambar 1. Kerangka Teoritik Faktor yang mempengaruhi Kinerja Karyawan

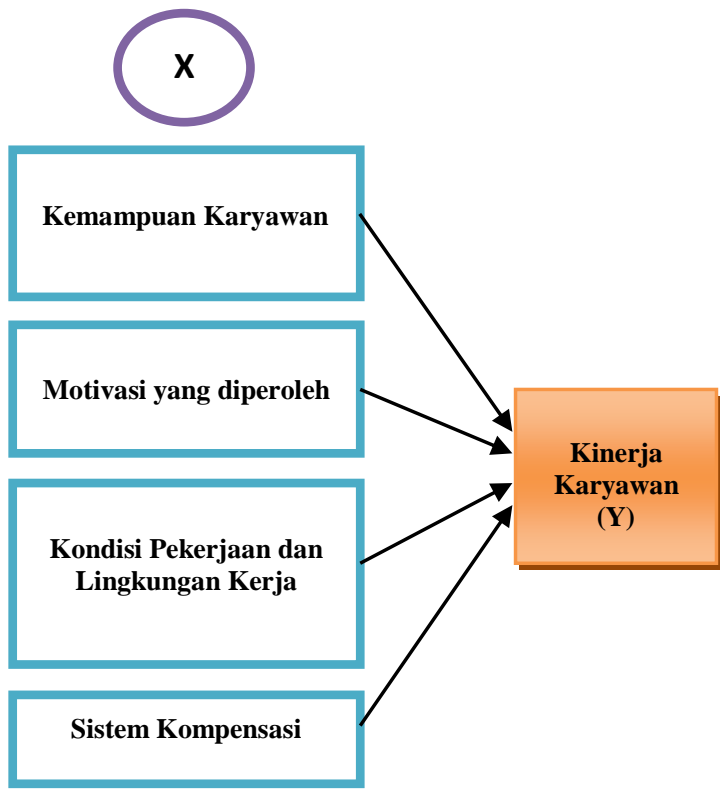

Sumber : Data olahan mandiri

Berdasarkan gambar di atas dapat kita simpulkan bahwa kemampuan karyawan, motivasi yang diperoleh karyawan, kondisi dan lingkungan kerja serta sistem kompensasi dapat mempengaruhi munculnya kualitas kerja atau kinerja karyawan dalam mencapai tujuan yang diharapkan dalam sebuah organisasi.

\section{II.b.1. Proses Rekrutmen Karyawan}

Penting sekali bagi sebuah organisasi untuk memperhatikan dan mempertimbangkan proses rekrutmen karyawan dalam rangka meminimalisir munculnya permasalahan terhadap kinerja karyawan dimasa yang akan datang yang dapat berdampak terhadap pencapaian tujuan organisasi tersebut.

Menurut T. Hani Handoko (2000:69), berpendapat bahwa Penarikan (recruitment) adalah proses pencarian dan pemikatan para calon karyawan (pelamar) yang mampu untuk melamar sebagai karyawan. 
Sedangkan menurut Rachmawati (2008:84), rekrutmen sumber daya manusia merupakan proses mencari, menemukan dan menarik para calon karyawan untuk memperkerjakan dalam dan oleh organisasi. Rekrutmen juga merupakan serangkaian kegiatan mencari dan memikat pelamar kerja dengan motivasi, kemampuan, keahlian, dan pengetahuan yang diperlukan untuk menutupi kekurangan yang diidentifikasi dalam perencanaan kepegawaian.

Berdasarkan pengertian dari para ahli tersebut maka dapat dikatakan bahwa rekrutmen merupakan serangkaian aktivitas untuk mencari, menemukan, menarik dan memikat para calon karyawan (pelamar) dengan motivasi, kemampuan, keahlian, dan pengetahuan yang diperlukan untuk dipekerjakan dalam suatu organisasi.

Adapun berbagi sumber rekrutmen menurut Mangkunegara (2009:34) yaitu ada dua sumber dalam penarikan pegawai, yaitu sumber dari dalam perusahaan yang diupayakan melalui mutasi pegawai yang mencakup promosi jabatan, transfer dan demosi jabatan. Kedua, sumber dari luar perusahaan yang diupayakan melalui iklan media massa, lembaga pendidikan dan depnaker.

a. Sumber dari Dalam Perusahaan

Upaya penarikan pegawai dapat dilakukan melalui proses memutasikan pegawai berdasarkan hasil evaluasi terhadap penilaian prestasi kerja pegawai yang ada di perusahaan. Ada tiga bentuk mutasi pegawai, yaitu:

- Promosi jabatan, yaitu pemindahan pegawai dari satu jabatan ke tingkat jabatan yang lebih tinggi daripada jabatan sebelumnya.

- Transfer atau rotasi pekerjaan adalah pemindahan bidang pekerjaan pegawai kepada bidang pekerjaan lainnya tanpa mengubah tingkat jabatannya.

- Demosi jabatan adalah penurunan jabatan pegawai dari satu jabatan ke tingkat jabatan yang lebih rendah atas dasar kondite dan prestasi kerjanya atau akibat terjadinya penyederhanaan struktur organisasi.

b. Sumber dari Luar Perusahaan

- Iklan Media Massa

Dalam hal ini perusahaan dapat memanfaatkan media massa sebagai sumber penawaran formasi kerja kepada masyarakat luas. Dengan menggunakan media massa tersebut dimungkinkan banyak lamaran kerja yang masuk ke perusahaan. Dengan demikan, memungkinkan perusahaan dapat menyeleksi calon pegawai yang betul-betul memenuhi persyaratan kualifikasi sesuai yang dibutuhkan untuk mengisi formasi yang ada di perusahaan.

- Lembaga Pendidikan

Perusahaan dapat memanfaatkan lembaga pendidikan sebagai sumber penarikan pegawai. Dengan melalui lembaga pendidikan, perusahaan dapat memanfaatkan referensi atau rekomendasi dari pemimpin lembaga pendidikan mengenai calon yang memenuhi kualifikasi yang tepat untuk mengisi formasi yang ada di perusahaan. Calon pegawai yang mendapat rekomendasi dari lembaga pendidikan pada umumnya merupakan calon pegawai yang mempunyai prestasi akademik yang tinggi dan mempunyai kepribadian yang dinilai baik selama mereka menempuh pendidikan di lembaga pendidikan tersebut.

- Depnaker

Perusahaan dapat memanfaatkan calon pegawai yang mendapat rekomendasi dari Departemen Tenaga Kerja. Dalam hal ini merupakan kewajiban perusahaan dalam rangka membantu program pemerintah dalam menyalurkan 
penduduk pencari kerja dan pengurangan pengangguran.

- Lamaran Kerja yang sudah masuk di Perusahaan

Lamaran kerja yang sudah masuk di perusahaan perlu dipertimbangkan sebagai sumber penarikan pegawai. Melalui lamaran kerja yang sudah masuk, perusahaan dapat langsung menyeleksi lamaran yang memenuhi kebutuhan untuk mengisi formasi yang ada di perusahaan.

Adapun tujuan adanya proses rekrutmen ini menurut Sondang P. Siagian (2009), yaitu :

a. Menyediakan sekumpulan calon tenaga kerja/karyawan yang memenuhi syarat.

b. Agar konsisten dengan strategi, wawasan dan nilai perusahaan.

c. Untuk membantu mengurangi kemungkinan keluarnya karyawan yang belum lama bekerja.

d. Untuk mengkoordinasikan upaya perekrutan dengan program seleksi dan pelatihan.

e. Untuk memenuhi tanggungjawab perusahaan dalam upaya menciptakan kesempatan kerja.

Selanjutnya Randall S. Schuler dan Susan E. Jackson (1997:227) menjelaskan bahwa kegiatan kunci yang merupakan bagian dari proses rekrutmen adalah:

a) Menentukan kebutuhan jangka pendek dan jangka panjang perusahaan dalam hal jenis pekerjaan (job title) dan levelnya dalam perusahaan.

b) Terus berupaya mendapatkan informasi mengenai perkembangan kondisi pasar tenaga kerja.

c) Menyusun bahan-bahan rekrutmen yang efektif.

d) Menyusun program rekrutmen yang sistematis dan terpadu yang berhubungan dengan kegiatan sumber daya manusia lain dan dengan kerja sama antara manajer lini dan karyawan.

e) Mendapatkan pool calon karyawan yang berbobot atau memenuhi syarat.

f) Mencatat kualitas dan jumlah pelamar dari berbagai sumber dan masing-masing metode rekrutmennya.

g) Melakukan tindak lanjut terhadap para calon karyawan baik yang diterima maupun yang ditolak, guna mengevaluasi efektif tidaknya rekrutmen yang dilakukan. Dan yang paling penting semua kegiatan ini harus dilakukan sesuai konteks hukum yang berlaku suatu pool yang berisikan para calon karyawan yang memenuhi syarat yang kemungkinan besar akan terpilih dan ditempatkan. Meskipun demikian, ternyata dalam kenyataannya rekrutmen belum tentu berhasil dengan baik, hal ini sangat terkait dengan berbagai kendala yang dihadapi. 


\section{Gambar 2. Gambar Proses Kegiatan Rekrutmen}

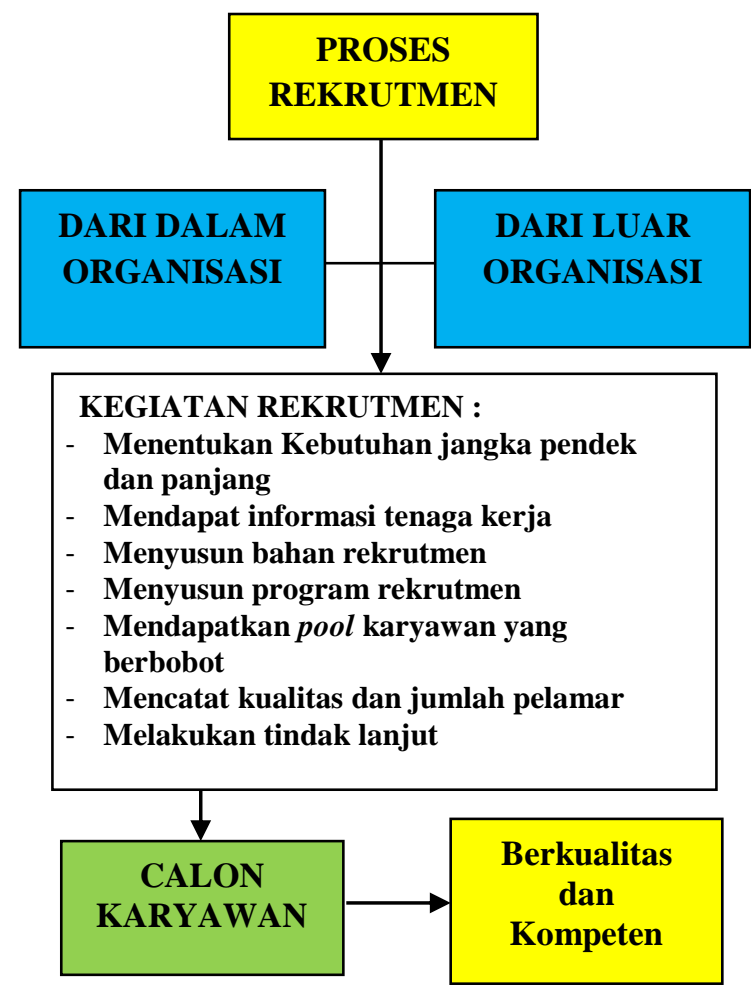

Dari pembahasan mengenai pentingnya perencanaan proses rekrutmen dalam sebuah organisasi dapat disimpulkan bahwa kegiatan rekrutmen merupakan suatu kegiatan yang terpenting untuk mendapatkan karyawan yang berkualitas dan berkompeten sesuai yang diinginkan oleh sebuah organisasi. Suatu hal yang mustahil apabila seandainya sebuah organisasi tidak memperhatikan proses rekrutmen karyawan ini dengan baik, karena bukan tidak mungkin akan terjadi kesalahan menempatkan seseorang bukan pada tempat dan kemampuannya justru hal ini dapat menghambat kinerja karyawan tersebut dimasa yang akan datang. Tentunya hal ini dapat merugikan organisasi tersebut.

Untuk itu kegiatan rekrutmen ini hendaknya dilaksanakan dengan sebaikbaiknya berdasarkan prosedur yang semestinya dalam rangka meminimalisir resiko yang akan terjadi pada sebuah organisasi dimasa yang akan datang.

\section{II.b.2. Pentingnya Penilaian Kinerja}

Menurut Bernardin dan Russel yang diterjemahkan oleh Khaerul Umam (2010:190-191), mengemukakan bahwa:

"Penilaian kinerja adalah cara
mengukur kontribusi individu
(karyawan) pada organisasi tempat
merekabekerja".

Sedangkan, Menurut Sedarmayanti (2011:261), mengemukakan bahwa :

"Penilaian kinerja adalah sistem formal untuk memeriksa/mengkaji dan mengevaluasi secara berkala kinerja seseorang."

Menurut Anwar Prabu Mangkunegara (2004), penilaian prestasi kerja sebagai proses yang dilakukan perusahaan dalam mengevaluasi kinerja pekerjaan seseorang.

Sedangkan menurut Hasibuan (2003: 105), penilaian prestasi kerja adalah suatu hasil kerja yang dicapai seseorang dalam melakukan tugas-tugas yang dibebankan kepadanya yang didasarkan pada kecakapan, pengalaman dan kesungguhan serta ketepatan waktu. Prestasi kerja ini sendiri ditentukan oeh beberapa faktor yakni kemampuan dan minat, kemampuan dan penerimaan atas penjelasan delegasi tugas dan peran, serta tingkat motivasi seorang pekerja.

Dari hasil pembahasan di atas, maka pelaksanaan penilaian prestasi kerja di dalam suatu organisasi sangatlah penting. Dengan penilaian prestasi pihak perusahaan dapat mengambil tindakan yang dapat dilakukan untuk meningkatkan 
keterampilan dan mengembangkan karyawannya, sesuai dengan potensi dan keterampilan dari karyawan tersebut. Selain itu, penilaian kinerja pegawai sangat perlu dilakukakan, karena dapat dijadikan sebagai bahan evaluasi terhadap setiap pegawai.

Penilaian prestasi pegawai ini memiliki istilah yang beragam dikalangan para ahli namun tetap memiliki makna yang sama, diantaranya adalah :

- Performance Rating

- Performance Appraisal

- Personal Assessment

- Employe Evaluation

- Merit Rating

- Efficiency Rating

- Service Rating

Leon C. Megginson (seperti dikutip Mangkunegara, 2004: 12) mengemukakan bahwa

"Performance appraisal is the process an employer uses to determine whether an employee is performing the job as intended" ( Performance Appraisal adalah suatu proses yang digunakan majikan untuk menentukan apakah seorang pegawai melakukan pekerjaannya sesuai dengan yang dimaksudkan ).

Berdasarkan beberapa istilah mengenai penilaian kerja di atas maka dapat kita simpulkan bahwa penilaian kerja merupakan suatu proses yang sangat penting yang dapat dilakukan oleh sebuah organisasi dalam mengevaluasi kerja pegawai dengan harapan hasil penilaian ini nantinya akan memberikan masukan terhadap kekurangan dan kelebihan seorang pekerja.
Selain itu, penilaian kerja ini diarahkan sebagai upaya untuk mampu mengembangkan potensi pegawai karena melalui hasil yang diperoleh dari proses penilaian kerja seorang pegawai ini nantinya akan dapat dijadikan sebagai bahan referensi perusahaan untuk bertindak dalam memberikan reward atau pengahargaan kepada karyawan yang memiliki hasil penilaian yang baik dan memberikan peringatan bagi karyawan yang kinerjanya menurun. Pada prakteknya penilaian kerja yang rasional dan transparan secara tidak langsung diharapkan mampu memberikan rangsangan kepada setiap pekerja untuk bekerja lebih baik lagi.

\section{II.b.3. Tujuan Penilaian Kinerja}

Berdasarkan pembahasan mengenai pentingnya penerapan penilaian kerja dalam sebuah instansi ini juga dapat dilihat penjelasannya melalui tujuan penilaian kinerja oleh beberapa ahli seperti uraian berikut ini.

Menurut Syafarudin Alwi yang dikutip oleh Khaerul Umam (2010:191), mengemukakan bahwa:

"Secara teoritis, tujuan penilaian kinerja dikategorikan sebagai suatu yang bersifat evaluation dan development. Suatu yang bersifat evaluation harus menyelesaikan:"

a. Hasil penilaian digunakan sebagai dasar pemberian kompensasi

b. Hasil penilaian digunakan sebagai staffing decision

c. Hasil penilaian digunakan sebagai dasar mengevaluasi sistem seleksi

Sedangkan yang bersifat development penilai harus menyelesaikan :

a. Prestasi real yang dicapai individu 

b. Kelemahan-kelemahan yang menghambat kinerja
c. Prestasi-prestasi dikembangkan
individu
yang

Menurut Sedarmayanti (2011:262) menjelaskan bahwa tujuan penilaian kinerja adalah :

1. Meningkatkan kinerja karyawan dengan cara membantu mereka agar menyadari dan menggunakan seluruh potensi mereka dalam mewujudkan tujuan organisasi.

2. Memberikan informasi kepada karyawan dan pimpinan sebagai dasar untuk mengambil keputusan yang berkaitan dengan pekerjaan.

Dari definisi tersebut dapat dikemukakan bahwa penilaian kinerja merupakan serangkaian proses untuk mengevaluasi proses atau hasil kerja seorang pegawai untuk memudahkan pimpinan (Kepala Bidang dan Kepala Dinas Koperasi, UKM, Perindustrian dan Perdagangan) dalam menentukan kebijakan bagi pegawai tersebut yang berkaitan dengan pekerjaan atau jabatannya.

\section{II.b.4. Manfaat Penilaian Kinerja}

$\begin{array}{ccc}\text { Menurut } & \text { Khaerul Umam } \\ \text { (2010:101), mengemukakan bahwa }\end{array}$ Kontribusi hasil penilaian merupakan suatu yang sangat bermanfaat bagi perencanaan kebijakan organisasi.secara terperinci, penilaian kinerja bagi organisasi adalah :

a. Penyesuaian-penyesuaian kompensasi

b. Perbaikan kinerja

c. Kebutuhan latihan dan pengembangan

d. Pengambilan keputusan dalam hal penempatan promosi, mutasi, pemecatan, pemberhentian, dan perencanaan tenaga kerja

e. Untuk kepentingan penelitian pegawai

f. Membantu diagnosis terhadap kesalahan desain pegawai
Berdasarkan beberapa uraian diatas maka kinerja individual dapat diukur, dimana pada tingkat individu ini berhubungan dengan pekerjaan, mengacu kepada tanggungjawab utama.

Bidang kegiatan utama atau tugas kunci yang merupakan bagian dari pekerjaan seseorang. Fokusnya kepada hasil yang diharapkan dapat dicapai seseorang dan bagaimana kontribusi mereka terhadap pencapaian target perorang, tim, departemen dan instansi serta penegakan nilai dasar Instansi.

\section{II. b. 5. Masalah dalam Penilaian Kerja Karyawan}

Penilaian mengandung beberapa kesalahan dan kelemahan karena penilaian pelaksanaan pekerjaan dilakukan oleh manusia. Kesalahan-kesalahan tertentu lebih lazim terdapat dalam beberapa metode ketimbang dalam metode-metode lainnya. Menurut T.Hani Handoko (1995:140-141) mengatakan bahwa ada 5 (lima) kendala dalam melakukan penilaian kinerja, yaitu :

\section{Halo Effect}

Kendala ini muncul ketika orang yang menilai memiliki hubungan dengan karyawan yang dinilai, menurut Handoko faktor tersebut akan mempengaruhi objektivitas atau berpotensi menimbulkan bias.

2. Kesalahan Kecenderungan Terpusat Penilai terkadang tidak merasa nyaman memberikan penilaian yang terlalu baik atau terlalu buruk sehingga hanya memberikan penilaian rata-rata.

3. Bias Terlalu Lunak dan Terlalu Keras Bila standar penilaian prestasi tidak jelas maka akan muncul kecenderungan penilai memberikan penilaian yang terlalu lunak maupun penilaian yang terlalu ketat.

4. Prasangka Pribadi.

Faktor-faktor yang membentuk prasangka pribadi terhadap seorang atau 
kelompok bisa mengubah penilaian. Sebab-sebab prasangka pribadi lain yang mempengaruhi penilaian mencakup faktor senioritas, kesukuan, agama, kesamaan kelompok dan status sosial.

5. Pengaruh Kesan Terakhir.

Kesan terakhir terkadang memberikan pengaruh yang dominan dalam proses penilaian. Bila suatu pekerjaan atau tugas berakhir maka penilaian akan baik pula namun jika berakhir buruk maka keseluruhan penilaian akan menjadi buruk.

Selain itu, Penilaian kerja pegawai dapat dikatan sebagai bentuk proses penilaian prestasi kerja pegawai yang dilakukan pemimpin perusahaan secara sistematik berdasarkan pekerjaan yang ditugaskan kepadanya.

Penilaian terhadap prestasi kerja pegawai dapat dilakukan oleh :

- Pemimpin perusahaan ( atasan langsung dan tidak langsung ).

- Kepala bagian personalia yang berhak memberikan penilaian prestasi terhadap semua pegawainya sesuai dengan data yang ada di bagian personalia.

Penilaian prestasi kerja pegawai perlu memperhatikan faktor-faktor rating pegawai yang diklasifikasikan melalui dua kelas, yakni :

1. Kualitas pribadi berhubungan dengan karakteristik atau sifat- sifat pribadi, sperti : kepercayaan, kreativitas, kemampuan verbal dan kepemimpinan.

2. Job yang berhubungan dengan tingkah laku. Beberapa faktor ini antara lain : kuantitas kerja, kualitas kerja dan keterampilan kerja.

Berdasarkan pembahasan yang telah dijelaskan di atas maka dapat dikatakan bahwa melalui penilaian prestasi pegawai yang akurat akan dapat memberikan masukan dan rekomendasi yang jelas bagi organisasi maupun sebuah perusahaan dalam mengevaluasi kinerja SDM dalam rangka memberikan apresiasi kepada karyawan untuk menumbuhkan motivasi dan meningkatkan kinerja pegawai.

\section{II.c. Kompensasi}

Menurut Husein Umar (2008:16) menyatakan bahwa kompensasi adalah :

\section{"Kompensasi adalah segala sesuatu yang diterima oleh pegawai berupa gaji, upah, insentif, bonus, premi, pengobatan, asuransi dan lain-lain yang sejenis yang di bayar langsung perusahaan".}

Sedangkan, menurut Mukaram dan Mawansyah (2000:127) mendefinisikan Kompensasi adalah penghargaan/ imbalan langsung maupun tidak langsung, finansial maupun non finansial yang adil dan layak kepada karyawan, sebagai balasan atas kontribusi mereka terhadap pencapaian tujuan organisasi.

“ Kompensasi merupakan balas jasa yang diberikan oleh organisasi / perusahaan kepada karyawan, yang dapat bersifat finansial maupun non finansial, pada periode yang tetap”.

Menurut Dessler

(2000) kompensasi/ pemberian balas jasa kepada karyawan mencakup beberapa hal berikut ini :

1. Pembayaran secara langsung (direct financial payment) dalam bentuk upah, gaji, insentif, dan bonus.

2. Pembayaran tidak langsung (indirect payment) dalam bentuk tunjangan seperti : asuransi, keuntungan (benefit) dan liburan atas dana organisasi.

3. Ganjaran nonfinansial (nonfinancial rewards) seperti hal-hal yang tidak mudah dikuantifikasi, yaitu ganjaran-ganjaran seperti : pekerjaan yang lebih menantang, 
jam kerja yang lebih luwes, promosi jabatan dan kantor yang lebih bergengsi, sehingga terciptanya kenyamanan dalam bekerja.

Penerapan kompensasi dalam suatu metode dan struktur praktek pekerjaan sebuah perusahaan maupun organisasi memiliki peran yang sangat sentral. Berikut beberapa alasan pentingnya pemberlakuan kompensasi :

- Melalui kompensasi yang baik akan mampu memberikan kepuasan bagi karyawan dan memungkinkan perusahaan mempekerjakan memperoleh,

mempertahankan karyawan.

- Kompensasi memiliki arti penting karena kompensasi mencerminkan upaya organisasi dalam mempertahankan dan meningkatkan kesejahteraan karyawannya.

- Pengalaman menunjukkan bahwa kompensasi yang tidak memadai dapat menurunkan prestasi kerja, motivasi kerja, dan kepuasan kerja karyawan, bahkan dapat menyebabkan karyawan yang potensial keluar dari perusahaan.

- Kompensasi merupakan alat pengikat perusahaan terhadap karyawannya, faktor penarik bagi calon karyawan dan faktor pendorong seseorang menjadi karyawan.

\section{II.c.1. Fungsi dan Tujuan Kompensasi}

Kompensasi mempunyai fungsi yang cukup penting di dalam memperlancar jalannya roda organisasi/ perusahaan. Menurut Martoyo (1994), fungsi kompensasi adalah:

a. Penggunaan SDM secara lebih efisien dan lebih efektif .

b. Mendorong stabilitas dan pertumbuhan ekonomi.
Sebagai bagian dari manajemen SDM, pemberian kompensasi bertujuan untuk :

1. Pemenuhan kebutuhan ekonomi karyawan atau sebagai jaminan economic security bagi karyawan.

2. Mendorong agar karyawan lebih baik dan lebih giat.

3. Menunjukkan bahwa perusahaan mengalami kemajuan.

4. Menunjukkan penghargaan dan perlakuan adil organisasi terhadap karyawannya.

Selanjutnya, kompensasi memilik tujuan tertentu dalam penerapannya dalam prkatek dunia kerja. Menurut Hasibuan (2008: 121), tujuan kompensasi adalah sebagai berikut :

1. Ikatan Kerja sama

Dengan pemberian kompensasi terjalinlah kerja sama formal antara perusahaan dengan karyawan. Karyawan harus mengerjakan tugastugasnya dengan baik, sedangkan pengusaha/majikan wajib membayar kompensasi sesuai dengan perjanjian yang disepakati.

2. Kepuasan Kerja

Dengan balas jasa, karyawan akan dapat memenuhi kebutuhan-kebutuhan fisik, status sosial, dan egoistiknya sehingga memperoleh kepuasan kerja dari jabatannya.

3. Pengadaan Efektif

Jika program kompensasi ditetapkan cukup besar, pengadaan karyawan yang qualified untuk perusahaan akan lebih mudah.

4. Motivasi

Jika balas jasa yang diberikan cukup besar, manajer akan mudah memotivasi bawahannya.

5. Stabilitas Karyawan

Dengan program kompensasi atas prinsip adil, layak dan kompetitif maka stabilitas karyawan lebih terjamin karena turn-over relatif kecil. 
6. Pengaruh Pemerintah

Jika program kompensasi sesuai dengan undang-undang perburuhan yang berlaku (seperti batas upah minimum) maka intervensi pemerintah dapat dihindarkan.

Dalam penerapan kompensasi ini tentunya memiliki sistem yang terukur, sistem pembayaran kompensasi yang umum diterapkan adalah :

1. Sistem Waktu

Dalam sistem waktu, besarnya kompensasi (gaji, upah) ditetapkan berdasarkan standar waktu seperti jam, minggu, atau bulan.

2. Sistem Hasil (Output)

Dalam sistem hasil, besarnya kompensasi/ upah ditetapkan atas kesatuan unit yang dihasilkan pekerja, seperti per potong, meter, liter, kilogram, dll.

3. Sistem Borongan

Sistem borongan adalah suatu cara pengupahan yang penetapan besarnya jasa didasarkan atas volume pekerjaan dan lama mengerjakannya. Dalam hal ini sistem pembayaran yang di terapkan menggunakan sistem waktu.

Pemberlakuan kompensasi dalam prakteknya memilii beberapa indikator seperti yang di kemukakan oleh Husein Umar (2007: 16) adalah :

1. Gaji

Imbalan yang di berikan oleh pemberi kerja kepada pegawai, yang penerimaannya bersifat rutin dan tetap setiap bulan walaupun tidak masuk kerja maka gaji akan tetap diterima secara penuh.

2. Insentif

Penghargaan atau ganjaran yang diberikan untuk memotivasi para pekerja agar produktivitas kerjanya tinggi, sifatnya tidak tetap atau sewaktu-waktu.

3. Bonus
Pembayaran sekaligus yang diberikan karena memenuhi sasaran kinerja.

4. Upah

Pembayaran yang diberikan kepada pegawai dengan lamanya jam kerja.

5. Premi

Premi adalah sesuatu yang diberikan sebagai hadiah atau derma atau sesuatu yang dibayarkan ekstra sebagai pendorong atau perancang atau sesuatu pembayaran tambahan di atas pembayaran normal.

6. Pengobatan

Pengobatan di dalam kompensasi adalah pemberian jasa dalam penanggulan resiko yang dikaitkan dengan kesehatan karyawan.

7. Asuransi

Asuransi merupakan penanggulangan risiko atas kerugian, kehilangan manfaat dan tanggung jawab hukum kepada pihak ketiga yang timbul dari peristiwa yang tidak pasti.

Kompensasi dalam kenyataannya merupakan faktor penting dan merupakan salah satu faktor utama dalam mewujudkan kinerja pegawai sebuah organisasi. Penerapan sistem kompensasi yang baik diharapkan akan dapat mewujudkan sistem pengelolaan tenaga kerja yang baik pula.

Dalam penerapan sistem kompensasi ini kepada karyawan atau pegawai tentunya akan dipengaruhi pula oleh kekuatan materi sebuah organisasi, semakin meningkat produktifitas sebuah organisasi maka diharapkan akan mampu memaksimalkan pemberian kompensasi kepada karyawan dalam rangka mewujudkan produktifitas karyawan tersebut.

Jumlah besaran kompensasi yang diberikan kepada karyawan oleh organisasi secara rasional memiliki keterikatan langsung dengan kekuatan dana sebuah organisasi. 
Analoginya adalah produktifitas yang dihasilkan oleh karyawan akan menghasilkan produktifitas sebuah organisasi secara keseluruhan. Dengan meningkatnya produktifitas sebuah organisasi tentunya akan dibarengi dengan maksimalnya pertumbuhan dana yang didapat sebuah organisasi, dari dana yang didapatkan oleh organisasi ini dapat menerapkan sistem kompensasi yang baik kepada karyawan dalam bentuk upah/ gaji maupun reward atau penghargaan.

\section{SIMPULAN}

Keberadaan sebuah organisasi dibarengi dengan seluruh sumber daya yang dimiliki, manusia sebagai aset hidup dalam sebuah organisasi dan fasilitas serta kelengkapan organisasi merupakan aset tidak hidup.

Manusia atau tenaga kerja dalam organisasi merupakan aset utama yang dapat mempengaruhi eksistensi sebuah organisasi secara langsung. Sebagai aset utama yang hidup, karena alasan inilah pengelolaan tenaga kerja dalam sebuah organisasi sangat penting sekali untuk dapat diterapkan secara baik dan sesuai dengan kaidah yang berlaku.

SDM atau tenaga kerja memilik unsur pikiran dan perasaan serta unsur fisik. Untuk melakukan pengelolaan yang baik kepada tenaga kerja tentunya perlu bagi pihak pengelola organisasi untuk mengerti dan memahami setiap unsur tersebut.

Melalui unsur fisik tentunya setiap pekerjaan yang berkaitan dengan pemanfaatn fisik perlu mempertimbangkan kemampuan fisik yang dimiliki oleh pegawai. Begitu pula untuk unsur pemikiran, perlu pula untuk memperhatikan tingkat kecerdasan yang dimilk oleh pegawai. Sedangkan, unsur perasaan berupa perhatian dan empati yang diberikan kepada tenaga kerja.
Pengelolaan SDM atau tenaga kerja yang dilandasi pemahaman mengenai unsur-unsur SDM tersebut dapat mengoptimalkan seluruh kemampuan yang dimiliki oleh tenaga kerja sehingga menciptakan produktifitas pegawai dalam bekerja dan memberikan keuntungan langsung kepada organisasi.

Namun, membutuhkan proses yang panjang dalam rangka memahami dan menerapkan pengelolaan SDM yang baik dalam sebuah organisasi.

Ada banyak faktor yang dapat mempengaruhi kinerja seorang pegawai dalam sebuah organisasi, yang mana setiap faktor memiliki formula tersendiri untuk dapat diselesaikan dengan baik oleh organisasi.

Pada dasarnya setiap masalah kinerja yang dihasilkan oleh pegawai atau tenaga kerja memiliki hubungan yang erat dengan pola kepemimpinan dan sistem manajemen dalam sebuah organisasi. Pemimpin adalah aktor utama penentu arah kebijakan seluruh bagian dalam sebuah organisasi. Sedangkan sistem manajemen merupakan kaidah dan aturan serta metode yang digunakan dalam melakukan pengelolaan seluruh sumber daya organisasi.

Melalui pola kepemimpinan dan sistem manajemen yang baik dapat menciptakan lingkungan kerja yang nyaman bagi anggota organisasi. Selanjutnya, melalui pola kepemimpinan dan sistem manajemen yang baik mampu mengatasi faktor-faktor penghambat terciptanya produktifitas kerja pegawai.

Pada dasarnya, produktifitas organisasi dapat terwujud apabila seluruh anggota organisasi memaksimalkan unsur SDM yang ada pada diri mereka yang berkaitan dengan kemampuan berpikir dan bekerja secara optimal dan total. Kenyataannya, memaksimalkan SDM ini 
membutuhkan sistem manajemen dan pola kepemimpinan yang baik.

\section{DAFTAR PUSTAKA}

Mangkunegara, A. A. Anwar Prabu. 2009a. Manajemen Sumber Daya Manusia Perusahaan. Bandung : PT. Remaja Rosda Karya. $2004 b$

Manajemen Sumber Daya Manusia Perusahaan. Bandung : PT. Remaja Rosdakarya.

Martoyo, Susilo. 1994. Manajemen Sumber Daya Manusia Edisi 2. Yogyakarta: BPFE.

Marwansyah, Mukaram. 2000. Manajemen Sumber Daya Manusia. Bandung : Politeknik Bandung Press.

Handoko, T. Hani. 2001a. Manajemen Personalia dan Sumber Daya Manusia. Yogyakarta: BPFE Yogyakarta. 2000b. Manajemen 2. Yogyakarta : BPFE. 1995c. Manajemen Personalia \& Sumber Daya Manusia. Yogyakarta : BPFEYogyakarta.

Hasibuan, Malayu S. P. 2005a. Manajemen Sumber Daya Manusia (Edisi revisi). Jakarta : Grasindo. 2003b. Manajemen Sumber Daya Manusia (Edisi Revisi). Jakarta : Bumi Aksara.

Rachmawati, Ike Kusdyah. 2008. Manajemen Sumber Daya Manusia. Yogyakarta : CV Andi Offsite.

Sedarmayanti. 2011. Manajemen Sumber Daya, Reformasi Birokrasi dan Manajemen Pegawai Negeri Sipil (cetakan ke lima). Bandung: PT. Refika Aditama.

Siagian, Sondang. P. 2009a. Manajemen Sumber Daya Manusia. Jakarta : Bumi Aksara.

2003b. Manajemen Sumber Daya Manusia (Edisi Revisi). Jakarta : Bumi Aksara.

Umam, Khaerul. 2010. Perilaku Organisasi. Bandung: Pustaka Setia

Umar, Husein. 2008. Desain Penelitian MSDM dan Perilaku Karyawan (Paradigma Positivistik dan Berbasis Pemecahan Masalah. Jakarta : PT. Rajagrafindo Persada. 